\section{Plant and Leaf Physiological Responses to Water Stress in Potted 'Vignoles' Grapevine}

\author{
Vania Lanari and Oriana Silvestroni \\ Dipartimento di Scienze Agrarie, Alimentari e Ambientali, Università \\ Politecnica delle Marche, Via Brecce Bianche, 60131 Ancona, Italy
}

\begin{abstract}
Alberto Palliotti
Dipartimento di Scienze Agrarie, Alimentari e Ambientali, Università di Perugia, Borgo XX giugno 74, 06128 Perugia, Italy
\end{abstract}

\section{Alan Green and Paolo Sabbatini ${ }^{1}$ \\ Department of Horticulture, Michigan State University, 1066 Bogue Street, East Lansing, MI 48824}

Additional index words. photosynthesis, carbon isotope, French-American hybrid, water limitation, leaf position

\begin{abstract}
Several studies have investigated water relationships in grapevines, but the responses to water limitation on individual leaves developed in different shoot positions are scarce in the literature. To begin to fill-in this gap, we examined the adaptive responses of vines at the leaf level to varying amounts of water stress using young hybrid 'Vignoles' in a controlled growth chamber. We found that the reduction in water availability to $40 \%$ of daily evapotranspiration limited shoot and leaf growth, affecting leaf number, shoot elongation, and leaf area. After 2 days of water stress we observed young developing leaves (nodes six to eight from the shoot apex) to have drastically reduced stomatal conductance $\left(g_{\mathrm{S}}\right.$, about $\left.20 \mathrm{mmol} \mathrm{H}_{2} \mathrm{O} / \mathrm{m}^{2} / \mathrm{s}\right)$ and net photosynthesis $\left(\mathrm{P}_{\mathrm{n}}, 2 \mu \mathrm{mol} \mathrm{CO}_{2} / \mathrm{m}^{2} / \mathrm{s}\right)$. On the 4th day $P_{n}$ in mature leaves (nodes 9 to 12 from the shoot apex) fell to values below $2 \mu \mathrm{mol}$ $\mathrm{CO}_{2} / \mathrm{m}^{2} / \mathrm{s}$. After 6 days, both $\mathrm{P}_{\mathrm{n}}$ and $g_{\mathrm{S}}$ stabilized at lower values with fluctuations related only to leaf position along the shoot axis. Young leaves revealed substantial enrichment of carbon-13 $\left({ }^{13} \mathrm{C}\right)$ and high water-use efficiency suggesting a higher and faster adaptive capacity to water shortage conditions as compared with mature leaves.
\end{abstract}

Not much is known about the influence of leaf position on photosynthesis in waterstressed leaves. We do know that stomatal control of water loss is an early plant response to water deficit under field conditions (Chaves, 1991; Cornic and Massacci, 1996) and that it contributes to a temporary reduction of leaf carbon fixation (Liu et al., 1978; Naor et al., 1994; Schultz, 2003). However, it has been reported for grapevines in the field that irreversible effects on photoinhibition occur when stomata are close during water deprivation and leaves are exposed to direct, high irradiance light for long periods of time (Medrano et al., 2003; Palliotti et al., 2008; Schultz, 1996; Silvestroni et al., 2005). Multiple summer stresses, such as high temperature, radiation

Received for publication 21 July 2015. Accepted for publication 25 Aug. 2015.

This research was in partial fulfillment of requirements for the Doctoral Degree of Dr. Vania Lanari and was supported by AgBioResearch at Michigan State University (Project GREEEN) as part of the cooperative agreement between the Department of Horticulture of Michigan State University and the Department of Agricultural, Food and Environmental Science of Polytechnic University of Marche. ${ }^{1}$ Corresponding author. E-mail: sabbatin@msu.edu. impact on the ratio between intercellular $\left(C_{\mathrm{i}}\right)$ and atmospheric $\left(C_{\mathrm{a}}\right)$ concentrations of $\mathrm{CO}_{2}$. In contrast to using gas exchange techniques that provide measurements of $\mathrm{P}_{n}$ rates at a single point in time, the $\Delta^{13} \mathrm{C}$ method offers the advantage of integrating physiological responses of plants to environmental stress (Brugnoli and Farquhar, 2000; Farquhar et al., 1982). The correlation between $\Delta^{13} \mathrm{C}$ and $C_{\mathrm{i}} / C_{\mathrm{a}}$ has been confirmed many times in different species and environmental conditions (Farquhar et al., 1989). Furthermore, the reduction in $g_{S}$ is associated with an optimization of intrinsic water-use efficiency (WUEi, the ratio of $\mathrm{P}_{\mathrm{n}}$ to $g_{\mathrm{S}}$ ), an indicator of long-term regulation of carbon assimilation under drought conditions (Bota et al., 2001; Cifre et al., 2005). The isotopic analysis of recently formed starch and sugar offers an estimate of the daily physiological response and, therefore, $\Delta^{13} \mathrm{C}$ related to short-term soil water availability. While the analysis of isotopic composition in leaf tissue represents not only $C_{\mathrm{i}} / C_{\mathrm{a}}$ and WUEi of the growing season, it also reflects the previous year's carbon assimilation and allocation. Thus, $\Delta{ }^{13} \mathrm{C}$ is related to long-term environmental changes (Brugnoli and Farquhar, 2000; de Souza et al., 2005; Gaudillère et al., 2002). Throughout the entire plant, the carbon isotope composition $\left(\delta^{13} \mathrm{C}\right)$ is dominated by $\mathrm{CO}_{2}$ assimilation and its diffusion into leaves via internal partitioning and the metabolism of primary assimilates produces differences in $\delta^{13} \mathrm{C}$ among plant tissues (Brugnoli and Farquhar, 2000; de Souza et al., 2005; Gleixner et al., 1993; Le Roux-Swarthout and Martin, 2001; Leavitt and Long, 1985).

Although the adaptive physiological changes of field-grown grapevines grown under water stress are well-known, less is known of grapevine performance under a more complex situation of simultaneous stress (e.g., water scarcity, excess light, and heat) even though it may be a more common occurrence in the summer and for lengthy periods. A preliminary container study in a controlled growth chamber is a useful model, whereby we can readily induce, control, and specifically study water stress alone or in tandem. The objective of this work was to evaluate the effects of water stress on the morphological and physiological responses of young 'Vignoles' potted grapevines in relation to leaf position and age and, subsequently, their ability to discriminate natural carbon isotope during photosynthesis.

\section{Materials and Methods} $\left(\mathrm{CO}_{2}\right)$ concentration at or slightly before full expansion (Alleweldt et al., 1982). The rate of $P_{n}$ then steadily declines as it ages toward senescence (Intrieri et al., 1992; Nicotra et al., 2003; Poni and Intrieri, 1996). Grape leaf $\mathrm{P}_{\mathrm{n}}$ is specifically known to peak $\approx 30$ to $40 \mathrm{~d}$ after unfolding and to decline thereafter (Intrieri et al., 1992; Kriedmann et al., 1970; Poni and Intrieri, 1996).

In plant species using the $\mathrm{C} 3$ form of photosynthesis, such as grapevine, both the environmental and internal factors that affect photosynthetic capacity and $g_{\mathrm{S}}$ are related to carbon isotope discrimination $\left(\Delta^{13} \mathrm{C}\right)$ via their
Plant material and experimental conditions. We carried out this trial in the Department of Horticulture of Michigan State University (East Lansing, MI) on young grapevines of the French-American hybrid 'Vignoles' (Ravat 51), a cross between 'Seibel 6905' and 'Pinot noir' (Galet, 1979). One-year-old vines were grown in 4-L black polyethylene containers filled with a 2 sand : 3 peat : 5 soil (by volume) mixture. We potted the vines on 10 May and placed them in a greenhouse under ambient light, temperature, and relative humidity. Vines 
were well watered and fertilized, and each shoot was staked at the beginning of the experiment. Three weeks before the application of the water-stress treatments, 12 vines, each with one primary shoot between 80 and $100 \mathrm{~cm}$ in length and 20 to 25 leaves, were transferred into a controlled growth chamber (model PGV36; Conviron, Winnipeg, Canada). Any senescent leaves in the basal node positions were removed. We followed by categorizing the remaining leaves into three classes by age: old (46-60 d), mature (31-45 d), and young (15-30 d), according to their position on the basal, medial, and distal parts of the shoot starting about from node 5 or $6 \mathrm{~cm}$ then to the apex including the last unfolding leaf. Water stress was applied for a period of $18 \mathrm{~d}$, during which the growth chamber was set to a daily cycle of $25^{\circ} \mathrm{C}$ for $16 \mathrm{~h}$ (daytime) followed by $18{ }^{\circ} \mathrm{C}$ for $8 \mathrm{~h}$ (nighttime). The photon flux density during each day was measured at 800 $\mu \mathrm{mol} \cdot \mathrm{m}^{-2} \cdot \mathrm{s}^{-1}$ (halogen lamps) and the relative humidity averaged $50 \%$.

We divided vines into two groups of six pots each to compare the effects of two different watering treatments: 1) full irrigation (well-watered vines: WW-vines), with daily manual irrigation to restore soil moisture lost by evapotranspiration and to maintain the soil at field capacity; and 2) limited irrigation (water-stressed vines: WS-vines), watered daily to replace only $40 \%$ (about) of the WW-vines daily evapotranspiration. The water supply for each treatment was determined daily by weighing each pot using an electronic balance (SB 32001 Delta Range; Mettler-Toledo Inc., Columbus, OH). Differences between daily successive irrigations and daily pot weight for each vine were used as the basis for calculations of the amount of water used by the vine as reported in Lavrenčič P et al. (2007). Each vine in both treatments was considered a replicate. We made measurements corresponding to control treatments on the first day of the experiment when all of the plants had been fully watered.

Vine morphology. At the end of the experiment, we measured shoot lengths and counted numbers of leaves in all vines. In addition, leaf area per shoot was measured using a leaf area meter (LI-COR Portable Area Meter model LI-3000; LI-COR Environmental, Lincoln, NE).

Gas exchange. Net photosynthesis, $g_{\mathrm{S}}$, and $C_{\mathrm{i}}$ at saturating light (1000 $\mu \mathrm{mol}$ photon/ $\mathrm{m}^{2} / \mathrm{s}$ ) were measured using a CIRAS-2 portable photosynthesis system (PP Systems Version 2.02; Amesbury, MA). Readings were taken on a leaf area of $2.5 \mathrm{~cm}^{2}$ when steady state conditions in gas exchange were achieved $(\approx 2 \mathrm{~min})$. The $\mathrm{CO}_{2}$ concentration $\left(375 \mu \mathrm{mol} \cdot \mathrm{mol}^{-1}\right)$ and leaf temperature $\left(30^{\circ} \mathrm{C}\right)$ inside the leaf cuvette were controlled by the CIRAS-2. Grapevine photosynthetic capacity was determined on the leaf at every node position in the morning (between 0900 and $1200 \mathrm{HR}$ ) at $1 \mathrm{~d}$ intervals from the beginning through day 12 of the experiment. The WUEi, $\mu \mathrm{mol} \mathrm{CO}_{2} / \mathrm{mol} \mathrm{H}_{2} \mathrm{O}$ ) was calculated as a ratio of $\mathrm{P}_{\mathrm{n}}: g_{\mathrm{S}}$.
Photosynthetic pigment analysis. Total chlorophyll and $a$ and $b$ chlorophyll contents were determined on two leaf discs (total area $=$ $2.3 \mathrm{~cm}^{2}$ ) taken from each leaf in the distal, medial, and basal shoot positions in both treatments. Discs were weighed and ground in a small mortar using a pestle with $\approx 2 \mathrm{~mL}$ of $80 \%$ acetone and then transferred to homogenizing tubes with an additional 2 to $3 \mathrm{~mL}$ of $80 \%$ acetone. Next, we transferred the substance to prechilled centrifuge tubes and refrigerated each for $10 \mathrm{~min}$ in the dark to precipitate proteins. The supernatant was then repeatedly decanted into prechilled graduated tubes until the green color was absent. Pigment concentrations of the extract were calculated by applying the Arnon equation (Arnon, 1949) to absorbance values recorded at 663,645 , and $470 \mathrm{~nm}$, respectively, using a spectrophotometer (Model ultraviolet-1601; Shimadzu Corporation, Kyoto, Japan).

Carbon isotope discrimination in dry leaf matter. Leaves for the determination of carbon isotope composition $\left(\delta^{13} \mathrm{C}\right)$ were sampled from distal, medial, and basal positions of the shoots at the end of the experiment. Leaves were oven dried at $85^{\circ} \mathrm{C}$ for $72 \mathrm{~h}$. Dried leaf samples were then ground with mortar and pestle into a fine homogeneous powder from which 1-mg subsamples were withdrawn for carbon isotope analysis. Carbon isotope content was measured using a continuous flow isotope ratio mass spectrometer (GC-MS; PDZ Europa 20-20 Mass Spectrometer and ANCA-GSL Sample Combustion Unit, PDZ Europa, Sandbach, UK). The $\delta^{13} \mathrm{C}$ was expressed as: $\delta^{13} \mathrm{C}=$ $[(\mathrm{Rs}-\mathrm{Rb}) / \mathrm{Rb}] \times 1000$, where $\mathrm{Rs}$ is the ratio ${ }^{13} \mathrm{C} /{ }^{12} \mathrm{C}$ of the sample and $\mathrm{Rb}$ is the ${ }^{13} \mathrm{C} /{ }^{12} \mathrm{C}$ of the Pee Dee Belemnite standard (Farquhar et al., 1989). Carbon isotope values were converted to discrimination values by the use of two equations:

$$
\Delta=(\delta a-\delta p) /(1+\delta p),
$$

where $\delta p$ refers to the isotopic composition of the leaf tissue and $\delta a$ refers to the isotopic composition of the $\mathrm{CO}_{2}$ in the atmosphere $(-8 \%)$, and

$$
\Delta=a+(b-a) \times(C \mathrm{i} / C \mathrm{a}),
$$

where the $\Delta^{13} \mathrm{C}$ value of $\mathrm{C} 3$ plants is related to the $C_{\mathrm{i}}$ and $C_{\mathrm{a}}$ ratio based on the model.

It was possible to calculate the theoretical values of $\delta^{13} \mathrm{C}$ using the carbon isotope discrimination formula proposed by Farquhar et al. (1989). The $C_{\mathrm{i}}$ values, taken during $\mathrm{P}_{\mathrm{n}}$ measurements, and the $C_{\mathrm{a}}$ value, $\approx 375$ $\mu \mathrm{mol} \cdot \mathrm{mol}^{-1}$, were inserted in Eq. [2]. Then, using Eq. [1] it was possible to calculate the theoretical values of leaf carbon isotope composition $(\delta p)$ where: $\delta p=(\delta a-\Delta) /(\Delta+1)$ with the objective to generate information on isotope signals during the water-stress period. Calculations were made when all vines were well-irrigated (day 0 ) and at the $6 \mathrm{~d}$ and $12 \mathrm{~d}$ points from the onset of water stress on leaves from the distal, medial, and basal shoot positions.

Statistical analysis. Results were tested for homogeneity of variance and subjected to analysis of variance (ANOVA) and mean separation test (Student-Newman-Keuls for $P \leq 0.05)$ was performed using Statgraphics software (version XV; Statpoint Incorporated, Herndon, VA). We used Sigma Plot software (version 10.0; SPSS Science, Chicago, IL) to obtain linear regressions. The effects of waterstress treatments were tested by one-way ANOVA and means separation was calculated by applying the Student-Newman-Keuls test at $P=0.05$ level. In the graphics data are shown as mean values \pm SE.

\section{Results}

Before the water stress application, with vines well-watered, the daily evapotranspiration $\left(\mathrm{ET}_{\text {daily }}\right)$ was similar for both treatments, $\approx 0.3 \mathrm{~L} / \mathrm{d}$, a value which the $\mathrm{WW}$-vines continued to stay near throughout the trial period (Fig. 1). The $\mathrm{ET}_{\text {daily }}$ of WS-vines gradually declined to a minimum of $\approx 0.13 \mathrm{~L} / \mathrm{d}$. From

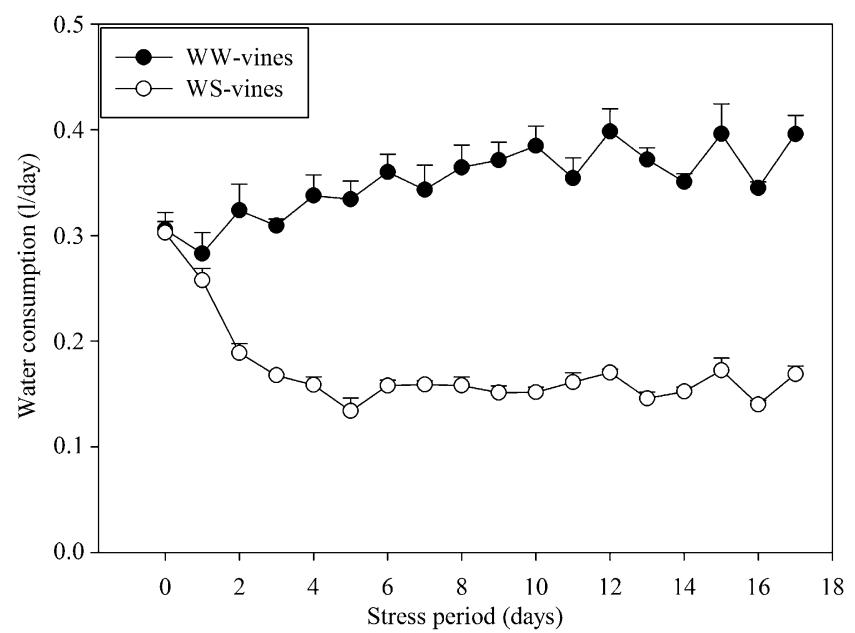

Fig. 1. Daily water consumption in pot-grown 'Vignoles' grapevines subjected to water stress: [40\% of daily well-watered vine (WW-vine) evapotranspiration; water-stressed vines (WS-vines)] and wellwatered $(100 \%$ of daily evapotranspiration; WW-vines) during the water stress period. Each point is the mean of six vines \pm SE. The day zero (0) corresponds to all WW-vines. 
the sixth day of the trial, WS-vines maintained a rate of $\approx 0.15 \mathrm{~L} / \mathrm{d}$ until the end of the experiment. Vine biometry was closely correlated to water limitation (Table 1). Compared with WW-vines, WS-vines had final shoot length $(-57 \%)$, leaf number $(-46 \%)$, and leaf area $(-71 \%)$ negatively impacted by the water limitation. Internode length and individual leaf area were also reduced by $\approx 20 \%$ and $46 \%$, respectively.

Before the water stress treatments $\mathrm{P}_{\mathrm{n}}$ values were about $5 \mu \mathrm{mol} \mathrm{CO}_{2} / \mathrm{m}^{2} / \mathrm{s}$ in both WWvines and WS-vines. At day 4 post-treatment the mean $\mathrm{P}_{\mathrm{n}}$ values of all WS-vines leaves were significantly reduced to $2 \mu \mathrm{mol} \quad \mathrm{CO}_{2} / \mathrm{m}^{2} / \mathrm{s}$, a figure which remained near constant until the end of the trial (Fig. 2A). In WW-vines, the mean $\mathrm{P}_{\mathrm{n}}$ values of all leaves were maintained between 4.5 and $6 \mu \mathrm{mol} \mathrm{CO} / \mathrm{CO}^{2} / \mathrm{s}$ during the experimental period (Fig. 2A).

At the beginning of the experiment, when all vines were well watered, $g_{\mathrm{S}}$ was similar in both treatments at values near $50 \mathrm{mmol} \mathrm{H}_{2} \mathrm{O}$ / $\mathrm{m}^{2} / \mathrm{s}$ (Fig. 2B). The $g_{\mathrm{S}}$ values in $\mathrm{WW}$-vines were maintained between 50 and $60 \mathrm{mmol}$ $\mathrm{H}_{2} \mathrm{O} / \mathrm{m}^{2} / \mathrm{s}$ until the end of the experiment showing a constant water status. The lowwater availability affected $g_{\mathrm{S}}$, which was significantly reduced after $2 \mathrm{~d}$ of water limitation by $\approx 30 \mathrm{mmol} \mathrm{H}_{2} \mathrm{O} / \mathrm{m}^{2} / \mathrm{s}$ and reached a minimum value of $20 \mathrm{mmol} \mathrm{H}_{2} \mathrm{O}$ / $\mathrm{m}^{2} / \mathrm{s}$ on day 6 (Fig. 2B).

On the second day of water stress, $C_{\mathrm{i}}$ in WS-vines were reduced to values lower than $180 \mu \mathrm{mol} \cdot \mathrm{mol}^{-1}$ from the initial values just below $200 \mu \mathrm{mol} \cdot \mathrm{mol}^{-1}$ in both treatments (Fig. 2C). After $4 \mathrm{~d}$ of water stress $C_{\mathrm{i}}$ in WS-vines increased sharply reaching a peak of $\approx 200 \mu \mathrm{mol} \mathrm{CO} / \mathrm{mol}$ and then leveling off at $190 \mu \mathrm{mol} \mathrm{CO} \mathrm{CO}_{2} / \mathrm{mol}$, slightly higher than WW-vines. Only on day 12 were $C_{\mathrm{i}}$ in the WS-vines characterized by lower values than in the WW-vines (Fig. 2C).

The WUEi values were similar in both treatments when all vines were well irrigated, $\approx 100 \mu \mathrm{mol} \mathrm{CO}_{2}: \mathrm{mol} \mathrm{H}_{2} \mathrm{O}$ (Fig. 2D). The rate of $\mathrm{P}_{\mathrm{n}}$, which is closely associated with the stomata restrictions, decreased in parallel to the reduction in $g_{\mathrm{S}}$ and a close relationship was found between $g_{\mathrm{S}}$ and $\mathrm{P}_{\mathrm{n}}$ (Fig. 3).

Treatment did not affect total chlorophyll concentration $(\mathrm{Chl} \mathrm{a}+\mathrm{b})$ or chlorophyll $\mathrm{a}: \mathrm{b}$ ratio (Table 2). The $\mathrm{Chl} \mathrm{a}+\mathrm{b}$ per unit area of the young leaves in the distal positions of WS-vines were $3.4 \%$ less than those of WWvines in the same locations, but without significant differences between treatments. Also, in mature leaves positioned in the medial portion of the shoot, the Chl $\mathrm{a}+\mathrm{b}$ per unit area were similar between the two treatments, but $\mathrm{Chl} \mathrm{a}+\mathrm{b}$ content observed in WW-vines was $9.8 \%$ lower than WS-vines (Table 2). In old stressed leaves, the total chlorophyll concentration per unit area was $5.2 \%$ lower than those in WW- vines. Both $\mathrm{Chl} \mathrm{a}+\mathrm{b}$ and $\mathrm{Chl} \mathrm{a}: \mathrm{b}$ ratios were similar in different leaf positions in both WW- and WStreatments (Table 2).

The physiological responses of leaves according to their position along the shoot axis shows that initially when all the vines

Table 1. Influence of water stress on vegetative growth of pot-grown 'Vignoles' grapevines as compared with well-watered control. Measurements taken at the end of the experiment on the apical shoot portion bearing four growing leaves at trial onset.

\begin{tabular}{lccccc}
\hline & $\begin{array}{c}\text { Shoot length } \\
(\mathrm{cm})\end{array}$ & $\begin{array}{c}\text { Internode length } \\
(\mathrm{cm})\end{array}$ & $\begin{array}{c}\text { Leaf size } \\
\left(\mathrm{cm}^{2}\right)\end{array}$ & $\begin{array}{c}\text { Leaf count } \\
(\text { No. })\end{array}$ & $\begin{array}{c}\text { Leaf area }^{\mathrm{z}} \\
\left(\mathrm{cm}^{2}\right)\end{array}$ \\
\hline WW-vines & $76.0 \mathrm{a}$ & $7.04 \mathrm{a}$ & $95.2 \mathrm{a}$ & $10.8 \mathrm{a}$ & $1028.0 \mathrm{a}$ \\
WS-vines $^{\mathrm{x}}$ & $32.9 \mathrm{~b}$ & $5.67 \mathrm{~b}$ & $51.4 \mathrm{~b}$ & $5.8 \mathrm{~b}$ & $298.3 \mathrm{~b}$ \\
Significance $^{\mathrm{w}}$ & $*$ & $*$ & $*$ & $*$ & $*$ \\
\hline
\end{tabular}

${ }^{\mathrm{z}}$ Mean per shoot calculated using Student-Newman-Keuls test.

${ }^{y}$ Vines watered daily with $100 \%$ of daily evapotranspiration.

${ }^{x}$ Vines watered daily with $40 \%$ of daily evapotranspiration of control vines.

${ }^{\text {w }}$ Significance $(*)$ : significant at $P=0.05$.

were well watered the $\mathrm{Pn}, g_{\mathrm{S}}$, and $C_{\mathrm{i}}$ values were quite similar independent of leaf position (Fig. 4). In WS-vines, after only $2 \mathrm{~d}$ of limited water supply, $\mathrm{P}_{\mathrm{n}}$ and $g_{\mathrm{S}}$ significantly decreased especially in distal and medial positions (i.e., from 5 to 13). The young leaves occupying the distal nodes were most affected by the low-water availability as evidenced by the lowered $g_{\mathrm{S}}$ of $\approx 20 \mathrm{mmol}$ $\mathrm{H}_{2} \mathrm{O} / \mathrm{m}^{2} / \mathrm{s}$ and $\mathrm{P}_{\mathrm{n}}$ below $3 \mu \mathrm{mol} \mathrm{CO} \mathrm{CO}_{2} / \mathrm{m}^{2} / \mathrm{s}$. The $C_{\mathrm{i}}$ values in these leaves were a little higher than others ranging from 150 to 200 $\mu \mathrm{mol} \cdot \mathrm{mol}^{-1}$ (Fig. 4).

On the fourth day of the water-stress treatment, mature leaves showed further reduction in $\mathrm{P}_{\mathrm{n}}$ reaching the minimum of $\approx 1.7$ $\mu \mathrm{mol} \mathrm{CO}_{2} / \mathrm{m}^{2} / \mathrm{s}$ without limiting $g_{\mathrm{S}}$ or $C_{\mathrm{i}}$ $\left(\approx 40 \mathrm{mmol} \mathrm{H} / \mathrm{O} / \mathrm{m}^{2} / \mathrm{s}\right.$ and over $200 \mu \mathrm{mol} \cdot \mathrm{mol}^{-1}$, respectively). From the sixth day of water stress onward the persistent water shortage led to a general lowering of $\mathrm{P}_{\mathrm{n}}$ (about $2 \mu \mathrm{mol} \mathrm{CO} /$ $\left.\mathrm{m}^{2} / \mathrm{s}\right)$ and $g_{\mathrm{S}}\left(\approx 20 \mathrm{mmol} \mathrm{H}_{2} \mathrm{O} / \mathrm{m}^{2} / \mathrm{s}\right)$ without marked fluctuations according to leaf position (Fig. 4). In the measurements conducted at 8, 10 , and $12 \mathrm{~d}$ of water shortage, no significant variations in $\mathrm{P}_{\mathrm{n}}$ and $g_{\mathrm{S}}$ by leaf position were observed and $C_{\mathrm{i}}$ were maintained at over 150 $\mu \mathrm{mol} \cdot \mathrm{mol}^{-1}$ (data not shown).

We calculated the values of $\delta^{13} \mathrm{C}$ by shoot position from the data obtained in the gas exchange measurements taken at 0,6 , and $12 \mathrm{~d}$ of water shortage (Table 3 ). After $6 \mathrm{~d}$ of water stress, the newly developed young leaves in the distal positions had significantly reduced discrimination capacity. The theoretical values of $\delta^{13} \mathrm{C}$ had risen to $-21.9 \%$ from $-24.4 \%$ measured at the beginning of the trial (Table 3). The prolonging of the water shortage for $12 \mathrm{~d}$ did not change the discriminatory capacity in the mature leaves, which remained quite stable during the water-stress period and similar to that in WW-vines. However, at the end of experiment the old leaves in the basal node positions, with an average age between 50 and $80 \mathrm{~d}$, showed the lowest values of theoretical $\delta^{13} \mathrm{C}$ maintaining high discrimination capacity, namely the lowest water-use efficiency regardless of water availability (Table 3 ). The ${ }^{13} \mathrm{C}$ analysis of leaf tissues at the end of the $18 \mathrm{~d}$ water-stress period provided information concerning the composition of carbohydrates present in the leaves, including both structural (those transferred from the reserve organs or formed largely before the trial) and those assimilated during the trial period. The leaf tissues of WW-vines were less rich in ${ }^{13} \mathrm{C}$ compared with those of

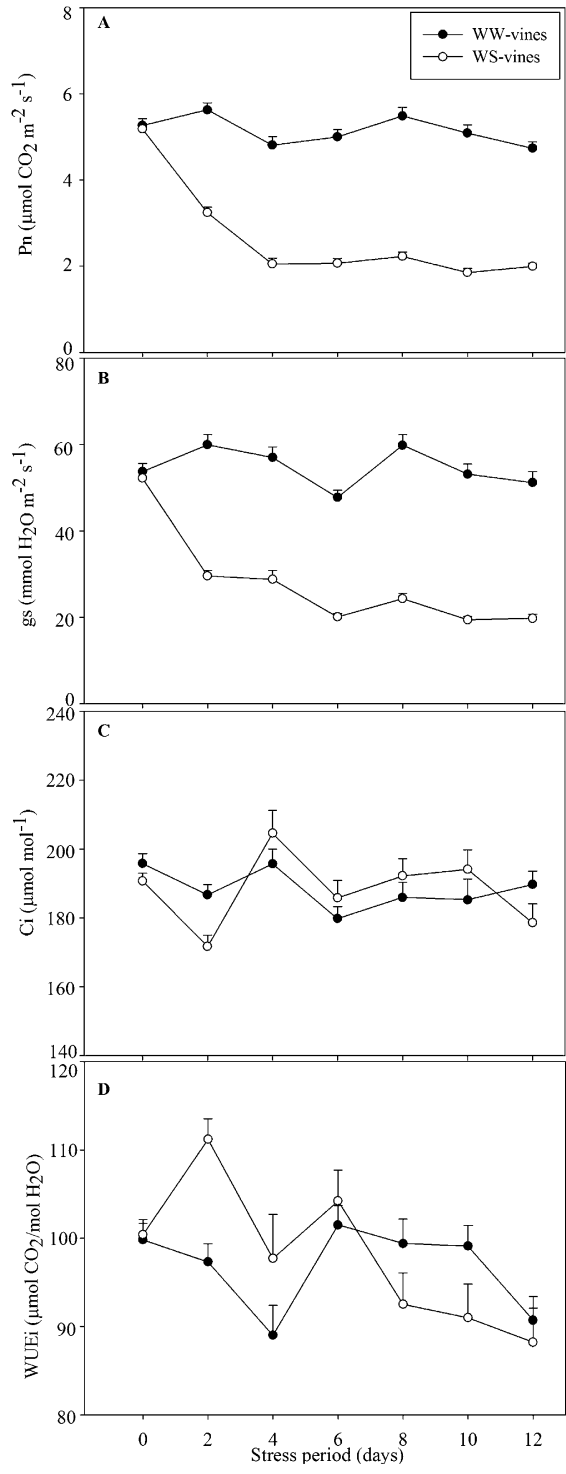

Fig. 2. Trend of (A) net photosynthesis $\left(\mathrm{P}_{\mathrm{n}}\right),(\mathbf{B})$ stomatal conductance $\left(g_{\mathrm{S}}\right),(\mathbf{C})$ intercellular $\mathrm{CO}_{2}$ concentration $\left(C_{\mathrm{i}}\right)$, and $(\mathbf{D})$ intrinsic water-use efficiency (WUEi) in pot-grown 'Vignoles' grapevines subjected to water stress $[40 \%$ of daily well-watered vines (WW-vines) evapotranspiration, water-stressed vines (WS-vines)] and well-watered $(100 \%$ of daily evapotranspiration, WW-vines) during the water stress period. Each point is the mean of six leaves \pm SE. The day zero (0) corresponds to all WW-vines.

WS-vines, which showed the lowest discriminatory capacity against atmospheric ${ }^{13} \mathrm{CO}_{2}$ and the highest ${ }^{13} \mathrm{C}$ concentration in young leaves at the distal shoot positions at $-24.3 \%$. 


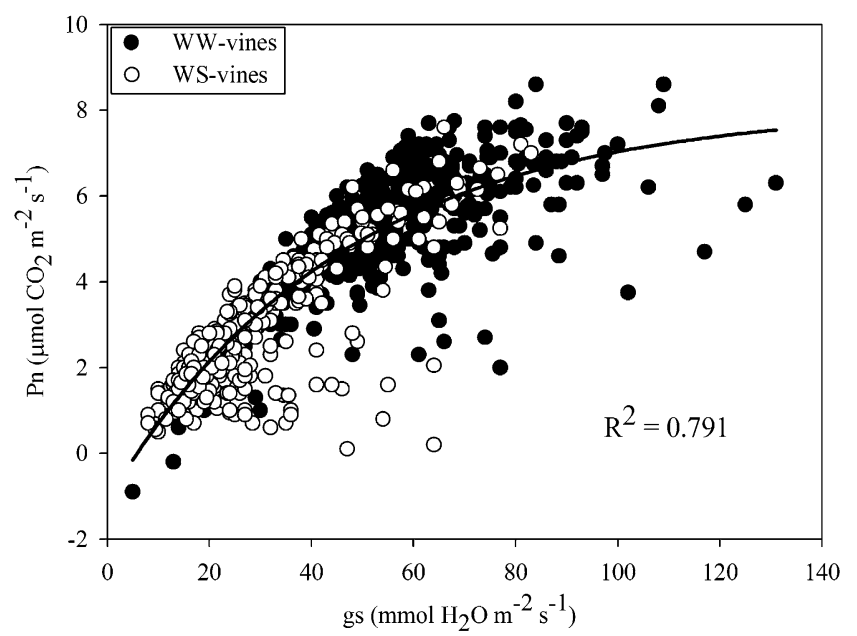

Fig. 3. Relationship between stomatal conductance $\left(g_{\mathrm{S}}\right)$ and net photosynthesis $\left(\mathrm{P}_{\mathrm{n}}\right)$ in pot-grown 'Vignoles' grapevines subjected to water stress $[40 \%$ of daily well-watered vines (WW-vines) evapotranspiration, water-stressed vines (WS-vines)] and well-watered (100\% of daily evapotranspiration, WW-vines). The best-fit adjustment is shown as a third-order nonlinear regression, Modified Hyperbola III

Table 2. Total chlorophyll concentration ( $\mathrm{Chl} a+b)$ and $\mathrm{Chl} a: b$ ratio determined at the end of the trial (after $18 \mathrm{~d}$ of water stress) of pot-grown 'Vignoles' grapevines as compared with the well-watered control.

\begin{tabular}{lcccccc}
\hline & \multicolumn{3}{c}{$\mathrm{Chl}(\mathrm{a}+\mathrm{b})\left(\mathrm{mg} / \mathrm{dm}^{2}\right)$} & \multicolumn{3}{c}{$\mathrm{Chl}(\mathrm{a} / \mathrm{b})\left(\mathrm{mg} / \mathrm{dm}^{2}\right)$} \\
\hline Treatment & $\mathrm{D}^{\mathrm{z}}$ & $\mathrm{M}$ & $\mathrm{B}$ & $\mathrm{D}$ & $\mathrm{M}$ & $\mathrm{B}$ \\
WW-vines $^{\mathrm{y}}$ & 3.8 & 3.7 & 4.1 & 3.5 & 3.3 & 3.1 \\
WS-vines $^{\mathrm{x}}$ & 3.7 & 4.1 & 3.9 & 3.3 & 3.3 & 3.2 \\
Significance $^{\mathrm{w}}$ & $\mathrm{NS}$ & $\mathrm{NS}$ & $\mathrm{NS}$ & $\mathrm{NS}$ & $\mathrm{NS}$ & $\mathrm{NS}$ \\
\hline
\end{tabular}

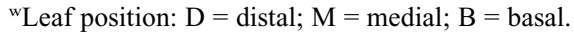

${ }^{y}$ Vines watered daily with $100 \%$ of daily evapotranspiration.

${ }^{x}$ Vines watered daily with $40 \%$ of daily evapotranspiration of control vines.

wSignificance: significant at $P=0.05$.

Carbon isotope concentration levels decreased from young leaves $(\approx-24 \%)$ to mature and old leaves $(\approx-26 \%)$, confirming the values found using the $\delta^{13} \mathrm{C}$ calculation (Table 3).

\section{Discussion}

Water shortage and the consequent reduction in the water flow through the plant negatively affect vine growth (Matthews et al., 1987; Shellie, 2006). The reduction of shoot length and leaf area of the vines is one of the most evident responses to water stress to reduce transpiration and, therefore, the loss of water (Taiz and Zeiger, 2002). Drought directly inhibits cell division and expansion (Zhu, 2002) and the reduction in growth is generally considered the most sensitive process under water stress conditions (Boyer, 1970; Hsiao, 1973). This outcome could be interpreted as an adaptive response to limit transpiring surface area. Moreover, slower growth allows plants to divert assimilate energy into protective molecules to combat stress and/or to maintain root growth and improve water uptake (Chaves et al., 2010). In grapevine, drought events occurring during the development of vine structures dampens vine growth (Palliotti et al., 2008, 2014; Poni et al., 1993). According to Palliotti et al. (2014), the limitation in the total leaf area per vine, assessed also in this study, subjected to water limitation was caused by fewer leaves per vine $(-46 \%)$ and smaller leaf size $(-29 \%)$, which correspond to an average of $-43.8 \mathrm{~cm}^{2}$ per leaf.

The measured $g_{\mathrm{S}}$ and $\mathrm{P}_{\mathrm{n}}$ values were very low in both treatments before the experiment and during the water-stress period. However, the photosynthetic activity of WW-vines was higher ( 5 to $6 \mu \mathrm{mol} \mathrm{CO} / \mathrm{m}^{2} / \mathrm{s}$ ) than that of WS-vines $\left(2 \mu \mathrm{mol} \mathrm{CO} / \mathrm{m}^{2} / \mathrm{s}\right)$. Water-stressed vines showed $g_{\mathrm{S}}$ values lower than $50 \mathrm{mmol}$ $\mathrm{H}_{2} \mathrm{O} / \mathrm{m}^{2} / \mathrm{s}$ after $2 \mathrm{~d}$ of water stress and remained low throughout the entire trial period. The values of WUEi obtained in this study confirm that in drought-adapted crops, grapevines have very high of WUEi (Bota et al., 2001; Moriana et al., 2002).

According to Cifre et al. (2005), the $g_{\mathrm{S}}$ values measured in our experiment indicate severe water stress and the occurrence of nonstomatal limitation to $\mathrm{P}_{\mathrm{n}}$. In such a situation, besides a steeper reduction in $\mathrm{P}_{\mathrm{n}}$, the WUEi decreases and the $C_{\mathrm{i}}$ steeply increases (Cifre et al., 2005; Düring, 1987; Flexas et al., 2002). In this experiment, when $g_{\mathrm{S}}$ reached minimum values $\left(20 \mathrm{mmol} \mathrm{H}_{2} \mathrm{O} / \mathrm{m}^{2} / \mathrm{s}\right)$ at day six, water stress was intensified and a decrease in WUEi was found because of a higher reduction of $g_{S}$ than $\mathrm{P}_{\mathrm{n}}$. In this phase, $C_{\mathrm{i}}$ values were maintained around $190 \mu \mathrm{mol}$ $\mathrm{CO}_{2} / \mathrm{mol}$ until day 12 , which showed lower values than $\mathrm{WW}$-vines suggesting that $\mathrm{CO}_{2}$ availability in the chloroplast could not to be regulated by $g_{\mathrm{S}}$. In contrast, although $g_{\mathrm{S}}$ values were very low, an increase in WUEi and a strong reduction of $C_{\mathrm{i}}$ (below $180 \mu \mathrm{mol} \cdot \mathrm{mol}^{-1}$ ) were observed after $2 \mathrm{~d}$ of water stress, suggesting that vines were being affected and the decrease in $C_{\mathrm{i}}$ indicates the stomatal limitations dominate, irrespective of any metabolic impairment (Flexas and Medrano, 2002). This discrepancy in $g_{\mathrm{S}}$ values, as an integrative parameter for the degree of water stress, could be explained by very low $g_{\mathrm{S}}$ values also in $\mathrm{WW}$-vines sometimes exceeding $60 \mathrm{mmol} \mathrm{H}_{2} \mathrm{O} / \mathrm{m}^{2} / \mathrm{s}$.

The hypothesis that the low photosynthetic activity was due predominantly to stomatal limitations was confirmed by the close curvilinear correlation $\left(R^{2}=0.8\right)$ found between $g_{\mathrm{S}}$ and $\mathrm{P}_{\mathrm{n}}$ (Fig. 3) in the study vines. This finding suggests that the reduction of $\mathrm{P}_{\mathrm{n}}$ registered in the WS-vines was due mainly to the stomata closure, consistent with reports for other varieties grown in the field (Cifre et al., 2005; Flexas et al., 1998; Palliotti et al., 2007). In addition, the total chlorophyll values determined at the end of the experiment in leaves from distal, medial, and basal shoot positions were similar in both treatments and in the same leaf position. Contrary to field experiments (Palliotti et al., 2008, 2014) and greenhouse work (Bertamini et al., 2006; Perez-Martin et al., 2009), the water deprivation in our experiments did not modify photosynthetic pigment concentrations, likely due to the lack of oxidative stress generally caused by conditions of high light and temperature.

Different $P_{n}$ values among leaves in different positions along the shoot characterized leaf gas-exchange measurements in the water stress treatment. The evolution of $\mathrm{P}_{\mathrm{n}}$ values is closely correlated to the discrimination of both ${ }^{13} \mathrm{CO}_{2}$ atmospheric and $\delta^{13} \mathrm{C}$ in leaf tissue (Farquhar et al., 1982, 1989). Theoretical $\delta^{13} \mathrm{C}$ calculations produced different $\delta^{13} \mathrm{C}$ values among young, mature, and senescent leaves along the shoot suggesting a different $\Delta^{13} \mathrm{C}$. According to gas exchange values, young leaves in the distal shoot positions suffered the effects of water shortage immediately ( $2 \mathrm{~d}$ from onset of water stress) and the first response was an immediate reduction in $g_{\mathrm{S}}$ and, as a consequence, a rapid reduction in $\mathrm{P}_{\mathrm{n}}$ activity. In this phase, $g_{\mathrm{S}}$ was low in relation to Rubisco capacity, $\Delta^{13} \mathrm{C}$ was regulated by diffusion, and $\Delta^{13} \mathrm{C}$ was reduced as underlined by theoretical $\delta^{13} \mathrm{C}$ values. Mature leaves in the medial positions of the shoot suffered the water limitation after $4 \mathrm{~d}$ from onset of water stress; they had $P_{n}$ values between those of young and old stressed leaves, and were characterized by intermediate theoretical $\delta^{13} \mathrm{C}$ values $(\approx-24 \%)$. Old leaves in the basal positions did not appear to be affected by water limitation, as underlined by low theoretical $\delta^{13} \mathrm{C}$ values (close to $-26 \%$ ). According to theoretical $\delta^{13} \mathrm{C}$ values and low $C_{\mathrm{i}}$ values (Table 3), indicative of decreased $C_{\mathrm{i}} / C_{\mathrm{a}}$ ratios, only after $12 \mathrm{~d}$ of water stress did the theoretical $\delta^{13} \mathrm{C}$ values increase to $-24 \%$, suggesting a reduction of $\Delta^{13} \mathrm{C}$. 


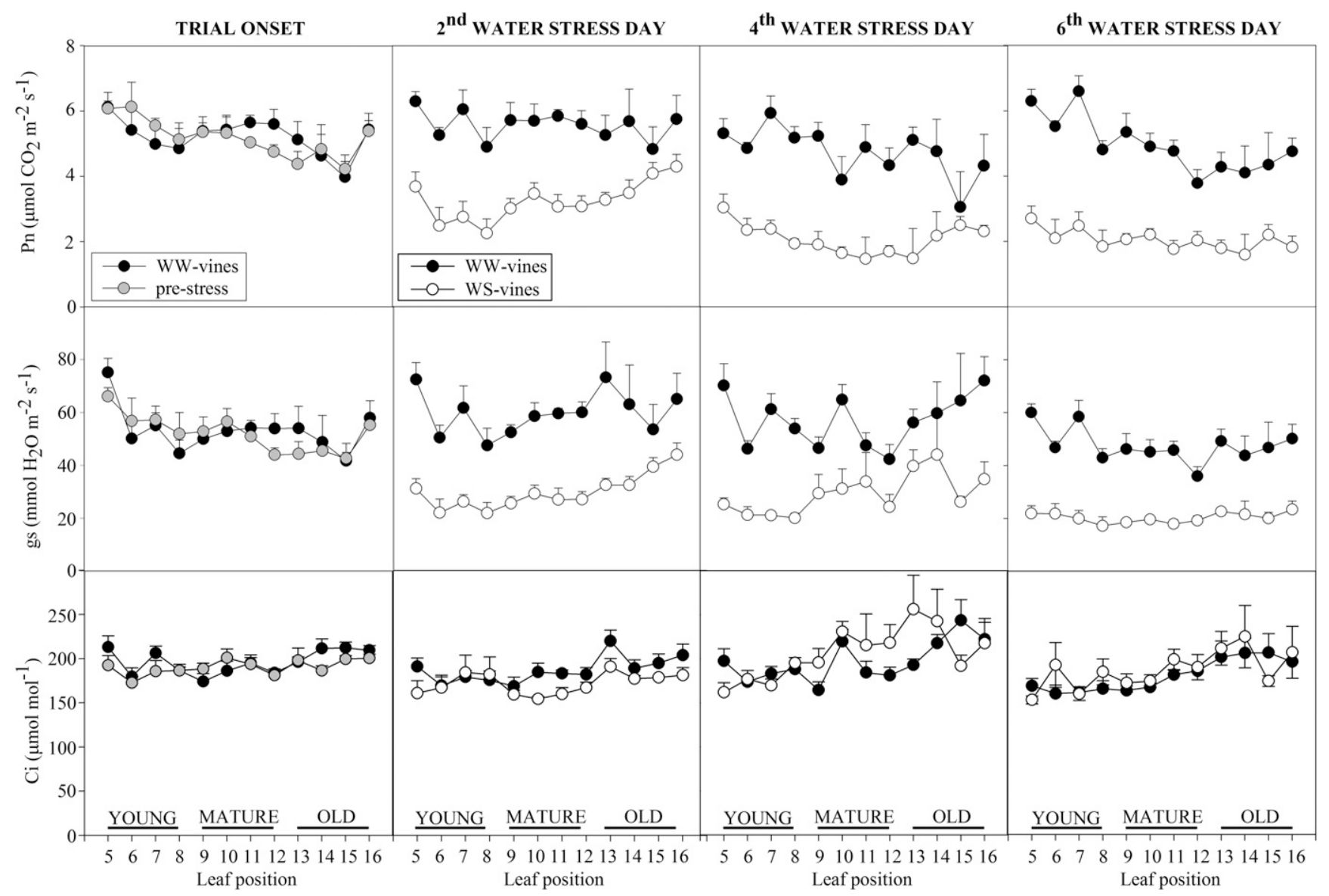

Fig. 4. Trend of net photosynthesis $\left(\mathrm{P}_{\mathrm{n}}\right)$, stomatal conductance $\left(g_{\mathrm{S}}\right)$, and intercellular $\mathrm{CO}_{2}$ concentration $\left(C_{\mathrm{i}}\right)$ of leaves in different position along the shoot, during the water stress period, in pot-grown 'Vignoles' grapevines subjected to water stress [ $40 \%$ of daily well-watered vines (WW-vines) evapotranspiration, waterstressed vines (WS-vines)] and well-watered (100\% of daily evapotranspiration, WW-vines). Each point is the mean of six replicates \pm SE. Leaf position was counted from the apex (position 5) of the shoot.

Table 3. Influence of water stress on theoretical carbon isotope composition (theoretical $\delta^{13} \mathrm{C}$ ) calculated at the trial onset, when all vines were well watered (day 0 ), after 6 and $12 \mathrm{~d}$ of water stress (day 6 and day 12). Measured carbon isotope composition (measured $\delta^{13} \mathrm{C}$ ) determined at the end of the trial (after $18 \mathrm{~d}$ of water stress) of pot-grown 'Vignoles' grapevines as compared with the well-watered control.

\begin{tabular}{|c|c|c|c|c|c|c|c|c|c|c|c|c|}
\hline \multirow[b]{3}{*}{ Leaves } & \multicolumn{9}{|c|}{ Theoretical $\delta^{13} \mathrm{C}(\%)$} & \multirow{2}{*}{\multicolumn{3}{|c|}{$\begin{array}{c}\text { Measured } \delta^{13} \mathrm{C}(\%) \\
\text { Day } 18\end{array}$}} \\
\hline & \multicolumn{3}{|c|}{ Day 0} & \multicolumn{3}{|c|}{ Day 6} & \multicolumn{3}{|c|}{ Day 12} & & & \\
\hline & $\begin{array}{l}\text { WW- } \\
\text { vines }^{2}\end{array}$ & Prestress ${ }^{y}$ & Significance $^{\mathrm{x}}$ & WW-vines & $\begin{array}{l}\text { WS- } \\
\text { vines }\end{array}$ & Significance & $\begin{array}{l}\text { WW- } \\
\text { vines }\end{array}$ & WS-vines & Significance & $\begin{array}{l}\text { WW- } \\
\text { vines }\end{array}$ & $\begin{array}{l}\text { WS- } \\
\text { vines }\end{array}$ & Significance \\
\hline $\mathrm{M}$ & $-23.9 \mathrm{a}$ & -24.3 & NS & $-23.3 \mathrm{a}$ & $-23.9 \mathrm{ab}$ & NS & -24.4 & $-24.2 \mathrm{~b}$ & NS & $-26.4 \mathrm{~b}$ & $-26.0 \mathrm{~b}$ & NS \\
\hline B & $-25.5 \mathrm{~b}$ & -24.9 & NS & $-24.7 \mathrm{~b}$ & $-25.4 \mathrm{~b}$ & NS & -25.2 & $-24.3 b$ & NS & $-26.8 \mathrm{~b}$ & $-26.1 \mathrm{~b}$ & * \\
\hline Significance $^{x}$ & $*$ & NS & & * & * & & NS & * & & $*$ & $*$ & \\
\hline
\end{tabular}

Ns, *Significant at $P=0.05$.

${ }^{\mathrm{z}}$ Vines watered daily with $100 \%$ of daily evapotranspiration.

${ }^{\mathrm{y}}$ Vines watered daily with $40 \%$ of daily control vines evapotranspiration.

${ }^{\mathrm{x}}$ Means separated within columns by Student-Newman-Keuls test.

wLeaf position: $\mathrm{D}=$ distal; $\mathrm{M}=$ medial; $\mathrm{B}=$ basal.

Measures of carbon isotope concentration in the dry leaf matter of WS-vines were lower, demonstrating the water treatment effect. The $\delta^{13} \mathrm{C}$ measured on leaves along the subject shoots confirms that young stressed leaves in the distal positions suffered greatest from the effects of water limitation as characterized by a substantial enrichment of ${ }^{13} \mathrm{C}$ (maximum $\delta^{13} \mathrm{C}$ values) followed by lower $\Delta^{13} \mathrm{C}$. These leaves quickly adapted to water stress and showed a greater WUEi, according to the inverse relationship between $\Delta^{13} \mathrm{C}$ and wateruse efficiency by Farquhar et al. (1982, 1989). Mature and old stressed leaves were subjected less to water deprivation effects revealing an intermediate degree of water stress and resulting in a lower sensitivity and less rapid adaptability, as demonstrated by the lowest values of $\delta^{13} \mathrm{C}(-26.0 \%$ and $-26.1 \%$, respectively) and suggesting a lower WUEi and higher discrimination capacity compared with atmospheric ${ }^{13} \mathrm{CO}_{2}$.

\section{Conclusions}

The application of water stress, without excessive temperature and light, reduced both evapotranspiration and shoot growth, which suggests an adaptive response that reduces transpiration by leaf area limitation and, consequently, water loss. The low-water availability negatively influenced $g_{\mathrm{S}}$ and induced a significant decrease in $\mathrm{P}_{\mathrm{n}}$ associated with stomata closure. The close relationship between $g_{\mathrm{S}}$ and $\mathrm{P}_{\mathrm{n}}\left(R^{2}=0.8\right)$ and unmodified photosynthetic pigment concentrations suggest that: 1) the vines were subjected to moderate water stress despite the low $g_{S}$ values of around $20 \mathrm{mmol} \mathrm{H}_{2} \mathrm{O} / \mathrm{m}^{2} / \mathrm{s}$ and, 2 ) the impact on stressed leaves was ameliorated by stomata closure, considered the main factor responsible for the decrease in the net 
photosynthetic carbon uptake rate, without affecting chloroplast function and photochemical efficiency.

The young stressed leaves on the distal portion of the shoot showed a high capacity to adapt to water limitation through quick stomata closure, a lowering of the discrimination of atmospheric ${ }^{13} \mathrm{CO}_{2}$, and an increase of the WUEi. The mature and old leaves at the medial and basal shoot positions, respectively, appeared to adapt more slowly to water stress by maintaining high discriminatory capacity to ${ }^{13} \mathrm{CO}_{2}$ without concurrent increases in the WUEi.

\section{Literature Cited}

Alleweldt, G., R. Eibach, and E. Ruhl. 1982. Investigations on gas-exchange in grapevine. 1. Influence of temperature, leaf age, and daytime on net photosynthesis and transpiration. Vitis 16:93-100.

Arnon, D.I. 1949. Copper enzymes in isolated chloroplasts. Polyphenoloxidase in Beta vulgaris. Plant Physiol. 24:1-15.

Bertamini, M., L. Zulini, K. Muthuchelian, and N. Nedunchezhian. 2006. Effect of water deficit on photosynthetic and other physiological responses in grapevine (Vitis vinifera L. cv. Riesling) plants. Photosynthetica 44:151-154.

Boardman, N.K. 1977. Comparative photosynthesis of sun and shade plants. Annu. Rev. Plant Physiol. 28:355-377.

Bota, J., J. Flexas, and H. Medrano. 2001. Genetic variability of photosynthesis and water use in Balearic grapevine cultivars. Ann. Appl. Biol. 138:353-361.

Boyer, J.S. 1970. Leaf enlargement and metabolic rates in corn, soybeans, and sunflower at various water potentials. Plant Physiol. 46:233-235.

Brugnoli, E. and G.D. Farquhar. 2000. Photosynthetic fractionation of carbon isotopes, $p$. 399-434. In: R.C. Leegood, T.D. Sharkey, and S. Von Caemmerer (eds.). Photosynthesis: Physiology and metabolism: Advances in photosynthesis and respiration. Kluwer Academic Publishers, Dordrecht, the Netherlands.

Chaves, M.M. 1991. Effects of water deficits on carbon assimilation. J. Expt. Bot. 42:1-16.

Chaves, M.M., O. Zarrouk, R. Francisco, J.M. Costa, T. Santos, A.P. Regalado, M.L. Rodrigues, and C.M. Lopes. 2010. Grapevine under deficit irrigation: Hints from physiological and molecular data. Ann. Bot. 105:661-676.

Cifre, J., J. Bota, J.M. Escalona, H. Medrano, and J. Flexas. 2005. Physiological tools for irrigation scheduling in grapevine (Vitis vinifera L.). An open gate to improve water-use efficiency? Agr. Ecosyst. Environ. 106:159-170.

Cornic, G. 1994. Drought stress and high light effects on leaf photosynthesis, p. 297-313. In: N.R. Baker and J.R. Bowyer (eds.). Photoinhibition of photosynthesis: From molecular mechanisms to the field. BIOS Scientific Publishers, Oxford, UK.

Cornic, G. and A. Massacci. 1996. Leaf photosynthesis under drought stress, p. 347-366. In: N.R. Baker (ed.). Photosynthesis and environment: Advances in photosynthesis and respiration. Kluwer Academic Publishers, Dordrecht, the Netherlands.

de Souza, C.R., J.P. Maroco, T.P. dos Santos, M.L. Rodrigues, C.M. Lopes, J.S. Pereira, and M.M.
Chaves. 2005. Impact of deficit irrigation on water use efficiency and carbon isotope composition $\left(\delta^{13} \mathrm{C}\right)$ of field-grown grapevines under Mediterranean climate. J. Expt. Bot. 56:21632172.

Düring, H. 1987. Stomatal responses to alterations of soil and air humidity in grapevines. Vitis 2:9-18.

Farquhar, G.D., M.H. O'Leary, and J.A. Berry. 1982. On the relationship between carbon isotope discrimination and the intercellular carbon dioxide concentration in leaves. Austral. J. Plant Physiol. 9:121-137.

Farquhar, G.D., S.C. Wong, J.R. Evans, and K.T. Hubick. 1989. Photosynthesis and gas exchange, p. 47-69. In: H.G. Jones, T.J. Flowers, and M.B. Jones (eds.). Plants under stress. Cambridge University Press.

Flexas, J. and H. Medrano. 2002. Droughtinhibition of photosynthesis in C3 plants: Stomatal and non-stomatal limitation revisited. Ann. Bot. 89:183-189.

Flexas, J., J. Bota, J.M. Escalona, B. Sampol, and H. Medrano. 2002. Effects of drought on photosynthesis in grapevine under field condition: An evaluation of stomatal and mesophyll limitations. Funct. Plant Biol. 29:461-471.

Flexas, J., J.M. Escalona, and H. Medrano. 1998. Down-regulation of photosynthesis by drought under field conditions in grapevine leaves. Austral. J. Plant Physiol. 25:893-900.

Galet, P. 1979. A practical ampelography. Grapevine identification. Cornell University Press, Ithaca, NY.

Gaudillère, J.P., C. Leeuwen, N. Ollat, J.P. Goutouly, and F. Champagnol. 2002. ${ }^{13} \mathrm{C} /{ }^{12} \mathrm{C}$ discrimination measured in tartrate and sugars in mature grapevine berries. Acta Hort. 493:63-68.

Gleixner, G., H.J. Danier, R.A. Werner, and H.L. Schmidt. 1993. Correlation between the ${ }^{13} \mathrm{C}$ content of primary and secondary plant products in different cell compartments and that in decomposing basidiomycetes. Plant Physiol. 102:1287-1290.

Hunter, J.J. and J.H. Visser. 1988. Distribution of ${ }^{14} \mathrm{C}$-photosynthetate in the shoot of Vitis vinifera L. cv. Cabernet Sauvignon. II. The effect of partial defoliation. S. Afr. J. Enol. Viticult 9:10-15.

Hsiao, T.C. 1973. Plant response to water stress. Annu. Rev. Plant Physiol. 24:519-570.

Iacono, F. and K.J. Sommer. 1996. Photoinibition on photosynthesis in Vitis vinifera under field conditions: Effects of light climate and leaf position. Austral. J. Grape Wine Res. 2:10-20.

Intrieri, C., S. Poni, O. Silvestroni, and I. Filippetti. 1992. Leaf age, leaf position and photosynthesis in potted grapevines. Adv. Hort. Sci. 6:23-27.

Kriedmann, P.E., W.M. Kiewer, and J.M. Harrais. 1970. Leaf age and photosynthesis in Vitis vinifera L. Vitis 9:98-104.

Lavrenčič, P., P. Sivilotti, and E. Peterlunger. 2007. Root hydraulic properties of eight rootstocks during water stress. Acta Hort. 754:283288.

Leavitt, S.W. and A. Long. 1985. Stable-carbon isotopic composition of maple sap and foliage. Plant Physiol. 78:427-429.

Le Roux-Swarthout, V.J.T. and C.E. Martin. 2001. Deviation between $\delta^{13} \mathrm{C}$ and leaf intercellular $\mathrm{CO}_{2}$ in Salix interior cuttings developing under low light. Intl. J. Plant Sci. 162:1017-1024.
Liu, W.T., R. Pool, W. Wenkert, and P.E. Kriedemann. 1978. Changes in photosynthesis, stomatal resistance and abscisic acid of Vitis labrusca through drought and irrigation cycles. Amer. J. Enol. Viticult. 29:239-246.

Matthews, M.A., M.M. Anderson, and H.R. Schultz. 1987. Phenologic and growth responses to early and late season water deficits in Cabernet franc. Vitis 26:147-160.

Medrano, H., J.M. Escalona, J. Cifre, J. Bota, and J. Flexas. 2003. A ten-year study on the physiology of two Spanish grapevine cultivars under field conditions: Effects of water availability from leaf photosynthesis to grape yield and quality. Funct. Plant Biol. 30:607-619.

Moriana, A., F.J. Villalobos, and E. Fereres. 2002. Stomatal and photosynthetic responses of olive (Olive europaea L.) leaves to water deficits. Plant Cell Environ. 25:395-405.

Naor, A., B. Bravdo, and J. Gelobter. 1994. Gas exchange and water relations in field-grown 'Sauvignon blanc' grapevines. Amer. J. Enol. Viticult. 45:423-428.

Nicotra, A.B., R.L. Chazdon, and R.A. Montgomery. 2003. Sexes show contrasting patterns of leaf and crown carbon in a dioecious rainforest shrub. Amer. J. Bot. 90:347-355.

Palliotti, A., O. Silvestroni, D. Petoumenou, S. Vignaroli, and J.B. Berrios. 2008. Evaluation of low-energy demand adaptive mechanisms in Sangiovese grapevine during drought. J. Intl. Sci. Vigne Vin. 42:41-47.

Palliotti, A., S. Tombesi, O. Silvestroni, V. Lanari, M. Gatti, and S. Poni. 2014. Changes in vineyard establishment and canopy management urged by earlier climate-related grape ripening: A review. Sci. Hort. 178:43-54.

Perez-Martin, A., J. Flexas, M. Ribas-Carbò, J. Bota, M. Tomàs, J.M. Infante, and A. DiazEspejo. 2009. Interactive effects of soil water deficit and air vapour pressure deficit on mesophyll conductance to $\mathrm{CO}_{2}$ in Vitis vinifera and Olea europaea. J. Expt. Bot. 8:2391-2405.

Poni, S., A.N. Lakso, J.R. Turner, and R.E. Melious. 1993. The effects of pre- and post-veraison water stress on growth and physiology of potted Pinot Noir grapevines at varying crop levels. Vitis 32:7-214.

Poni, S. and C. Intrieri. 1996. Physiology of grape leaf ageing as related to improved canopy management and grape quality. Proc. Ninth Annu. Austral. Wine Ind. Tech. Conf. Winetitles. p. 113-122.

Schultz, H.R. 1996. Water relations and photosynthetic responses of two grapevine cultivars of different geographical origin during water stress. Acta Hort. 427:251-266.

Schultz, H.R. 2003. Differences in hydraulic architecture account for near-isohydric and anisohydric behaviour of two field-grown Vitis vinifera $\mathrm{L}$ cultivars during drought. Plant Cell Environ. 26:1393-1405.

Shellie, K.C. 2006. Vine and berry response of Merlot (Vitis vinifera $\mathrm{L}$.) to differential water stress. Amer. J. Enol. Viticult. 57:514-518.

Silvestroni, O., S. Mattioli, D. Neri, A. Palliotti, and A. Cartechini. 2005. Down-regulation of photosynthetic activity for field-grown grapevines. Acta Hort. 689:285-291.

Taiz, L. and E. Zeiger. 2002. Plant physiology. 3rd ed. Sinauer, Sunderland, MA.

Zhu, J. 2002. Salt and drought stress signal transduction in plants. Annu. Rev. Plant Biol. 53:247-273. 